\title{
Empirical Research of the Impact of Internet Finance on Personal Finance
}

\author{
Junwei Han a, Yuzhong Sun ${ }^{\text {b* }}$ \\ School of Accounting, Heilongjiang Bayi Agricultural University, Daqing 163319, China \\ a332453023@qq.com, bsunyuzhong@byau.edu.cn
}

\begin{abstract}
The development of the Internet finance has formed a huge impact on the current China's financial system, which inevitably has a major influence on the field of personal finance. The empirical analysis has carried on for the influence by using the survey data in this paper. The results show that factors of residents such as family income, investment structure, education level and age will have an impact on the "Internet finance cognition"; People recognize advantages of the Internet finance, but also misgive on the security of it; For the prospects of Internet finance, most people are still more optimistic, but they don't think the Internet finance can replace the Bank's current position.
\end{abstract}

Keywords: Internet Finance; Personal Finance; Traditional Finance.

\section{Introduction}

Since 2013 Internet finance rapidly rise. That produced profound influence on the traditional finance. The new financing method such as YUEBAO form a larger impact on the field of personal finance. That has important theoretical significance and application value for making policy of the development of Internet finance and grasping the development trend of the Internet finance to make analysis of the current people of the Internet financial awareness, choice intention and its influencing factors.

\section{Theory analysis of the influence of Internet finance on personal finance}

\subsection{The main advantages of Internet finance}

(1) Inclusive

Based network, the Internet finance breaks the space and time constraints existed in financial entities by virtue of its virtual nature. That can provide adequate financial services especially for groups with special needs. Internet financial universality greatly reduces the threshold of personal finance in the financial services, has realized the full coverage of different groups.

(2) Convenient

Internet finance use advanced Internet technology and modern communication technology to simplify the business process, shorten the business hours, achieve in a platform for various types of financial services integration, and enable customers to more efficient financial services.

(3) Safe

The safety of Internet finance comes from the widespread application of the modern computer technology, such as network firewall, digital signature and digital encryption technology; on the other hand from in widespread use of big data and cloud computing technology. Through combing and orderly sort of mass information, it greatly reduces the risk of the transaction and the possible loss.

\subsection{The impact on personal finance}

(1)Broaden the channels of personal finance

The channels of traditional personal finance include stock investment, fund investment, insurance and bank deposits. While Internet finance not only changes the financial products over the Internet, but also creates some new financing channels, such as P2P investment, crowd funding etc.

(2)Reduce the cost of personal finance

Internet Finance integrates a large number of modern technology, breaking the traditional finance due to time and space constraints caused by service barriers, forming a whole space, full-time new financial services model. 
(3)Strengthen the security of the personal finance

On the surface, the existence based on the virtual network, Internet finance seems that the security of it is not as good as the physical store as the characteristics of the traditional financial. In fact, as a result of the data encryption, digital secret key, massive data, cloud computing and other modern science and technology, safety of Internet finance is much higher than the traditional finance. The appearance of Internet finance makes investors more financial security.

\section{An empirical analysis of the impact of Internet finance on personal finance}

The team made a questionnaire for the impact of Internet finance to personal finance. The survey area covered Sichuan, Shanxi, Hebei, and Heilongjiang four provinces, a total of 200 questionnaires were distributed, the effective recovery of 196 parts. Participants were randomly, occupations generally have students, teachers, accountants, lawyers, sales staff, managers, free professionals, etc. The issues of questionnaire relate to "the impact of Internet finance cognitive factors", "the choice of Internet finance products", as well as "how to look at the prospects for the development of Internet finance".

\subsection{Analysis of impact factors for Internet finance cognition}

There are many factors that affect investors' cognition of Internet finance. The factors that the questionnaire survey mainly include "family income", "investment structure", "education level" and "age", etc.

(1) Family income

Table 1 Impact of family income on Internet finance cognition

\begin{tabular}{|c|c|c|c|c|c|c|c|c|c|}
\hline \multicolumn{2}{|c|}{} & \multicolumn{2}{c|}{ know well } & \multicolumn{2}{c|}{ know a little } & \multicolumn{2}{c|}{ unknown } & number & proportion \\
\hline \multirow{3}{*}{$\begin{array}{c}\text { Family } \\
\text { income } \\
\text { (ten } \\
\text { thousand } \\
\text { Yuan) }\end{array}$} & 5 & 2 & $2.63 \%$ & 39 & $51.32 \%$ & 35 & $46.05 \%$ & 76 & $38.78 \%$ \\
\cline { 2 - 11 } & $10 \sim 15$ & 8 & $11.43 \%$ & 42 & $60 \%$ & 20 & $28.57 \%$ & 70 & $35.71 \%$ \\
\cline { 2 - 11 } & $15 \sim 20$ & 1 & $7.69 \%$ & 10 & $76.92 \%$ & 2 & $15.39 \%$ & 13 & $6.63 \%$ \\
\cline { 2 - 10 } & $>20$ & 2 & $28.57 \%$ & 2 & $28.57 \%$ & 3 & $42.86 \%$ & 7 & $3.57 \%$ \\
\hline \multicolumn{2}{|c|}{ total } & 19 & $9.69 \%$ & 113 & $57.66 \%$ & 64 & $32.65 \%$ & 196 & $100 \%$ \\
\hline
\end{tabular}

Data analysis: The families surveyed whose income between 50000 Yuan and 200000 Yuan are defined as middle-income families. Table 1 show that the proportion of middle-income families is $57.66 \%$. That is in line with China's current basic national conditions. In the survey of cognition for Internet finance, selecting "know a little" of the survey accounted for also 57.66\%. That shows the development of the Internet finance in China is in the beginning stage and people who understand the Internet finance are not enough.

Further analysis can be found that middle-income families accounted for the largest families of all whose knowledge of the Internet finance for "know well" and "know a little". The cause of this result is accounted for the proportion of middle-income families is higher and the middle-income families are easy to accept new things.

Middle-income families have the material conditions of low-income families have no. So they are very easy to come into contact with the modern science and technology.

Middle-income families in a period to the development of the high income family, desperately want to accumulate more wealth. Due to the high barriers to entry the traditional financial services market, the enthusiasm of these families to enter the market was suppressed. While Internet finance markets provided the new investment channels for them. Relatively high income households have more wealth, more likely to choose a stable and less risky way of investment, more easy to hold a rejection on Internet finance as the new things. 
Revelation: currently, Internet finance cognitive higher customer group is mainly focused on middle-income families, so the needs of middle-income families should be focused on to provide more targeted products for developing the Internet finance market.

(2) Share of investment

Table 2 Impact of share of investment on Internet finance cognition

\begin{tabular}{|c|c|c|c|c|c|c|c|c|c|}
\hline \multicolumn{2}{|c|}{$(\%)$} & \multicolumn{2}{c|}{ Know well } & \multicolumn{2}{c|}{ know a little } & \multicolumn{2}{c|}{ unknown } & number & proportion \\
\hline \multirow{2}{*}{$\begin{array}{c}\text { investment } \\
\text { amount / } \\
\text { family } \\
\text { income }\end{array}$} & $<10$ & 6 & $5.17 \%$ & 66 & $56.9 \%$ & 44 & $37.93 \%$ & 116 & $59.18 \%$ \\
\cline { 2 - 10 } & $10 \sim 30$ & 2 & $5 \%$ & 25 & $62.5 \%$ & 13 & $32.5 \%$ & 40 & $20.41 \%$ \\
\cline { 2 - 10 } & $30 \sim 50$ & 7 & $25.93 \%$ & 15 & $55.56 \%$ & 5 & $18.52 \%$ & 27 & $13.78 \%$ \\
\hline \multicolumn{2}{|c|}{ total } & 4 & $30.77 \%$ & 7 & $53.85 \%$ & 2 & $15.38 \%$ & 13 & $6.63 \%$ \\
\hline
\end{tabular}

Currently on the Internet finance knowledge the proportion of "know a little" for family is the largest whether the family's proportion of Investment amount is small or big. That shows the current residents for Internet finance have a certain degree of understanding, but knowledge is not enough. Data also shows that the proportion of investment is proportional to the cognition of the Internet financial, in the investigation, the higher the proportion of investment, the lower of cognition about the Internet financial for "unknown". Possible for two reasons: first, the greater the proportion of investment means the bigger the investment demand. The investors are more willing to learn more financing way. That necessarily makes them to have deeper understanding of the Internet finance. Second, Economic condition of this kind of family is relatively good. They have more access to the Internet finance.

(3) Education

Table 3 Impact of education on Internet finance cognition

\begin{tabular}{|c|c|c|c|c|c|c|c|c|}
\hline \multirow{2}{*}{ Education } & \multicolumn{2}{|c|}{ Know well } & \multicolumn{2}{c|}{ know a little } & \multicolumn{2}{c|}{ unknown } & number & proportion \\
\hline $\begin{array}{c}\text { Junior college and } \\
\text { the following }\end{array}$ & 4 & $5 \%$ & 34 & $42.5 \%$ & 42 & $52.5 \%$ & 80 & $40.82 \%$ \\
\hline College & 5 & $11.63 \%$ & 27 & $62.79 \%$ & 11 & $25.58 \%$ & 43 & $21.94 \%$ \\
\hline Undergraduate & 7 & $11.67 \%$ & 42 & $70 \%$ & 11 & $18.33 \%$ & 60 & $30.61 \%$ \\
\hline Graduate or above & 3 & $23.08 \%$ & 10 & $76.92 \%$ & 0 & 0 & 13 & $6.63 \%$ \\
\hline Total & 19 & $9.69 \%$ & 113 & $57.66 \%$ & 64 & $32.65 \%$ & 196 & $100 \%$ \\
\hline
\end{tabular}

Table 3 shows: respondents with education as "Junior college and the following" the level of cognition for Internet finance of them as "unknown" accounted for 52.5\%. But that accounted for 0 for respondents with education as "Graduate or above". On the whole, the degree of cognition on Internet finance is directly proportional to the degree of the education of respondents. The higher the degree of the education means the deeper the cognition for Internet finance. People with higher education obviously easy to come into contact with new things, and are more likely to try and master new things.

(4) Age

Table 4 Impact of education on Internet finance cognition

\begin{tabular}{|c|c|c|c|c|c|c|c|c|}
\hline Age & \multicolumn{2}{|c|}{ Know well } & \multicolumn{2}{c|}{ know a little } & \multicolumn{2}{c|}{ unknown } & number & proportion \\
\hline$<25$ & 11 & $9.73 \%$ & 70 & $61.95 \%$ & 32 & $28.32 \%$ & 113 & $57.65 \%$ \\
\hline $25 \sim 35$ & 6 & $11.11 \%$ & 26 & $48.15 \%$ & 22 & $40.74 \%$ & 54 & $27.55 \%$ \\
\hline $36 \sim 45$ & 1 & $7.69 \%$ & 8 & $61.54 \%$ & 4 & $30.77 \%$ & 13 & $6.63 \%$ \\
\hline $46 \sim 55$ & 1 & $11.11 \%$ & 5 & $55.56 \%$ & 3 & $33.33 \%$ & 9 & $4.59 \%$ \\
\hline$>55$ & 0 & 0 & 4 & $57.14 \%$ & 3 & $42.86 \%$ & 7 & $3.57 \%$ \\
\hline total & 19 & $9.69 \%$ & 113 & $57.66 \%$ & 64 & $32.65 \%$ & 196 & $100 \%$ \\
\hline
\end{tabular}


Table 4 shows: overall, group as 45 years old and following have more understanding of the Internet finance. It is worth noting that respondent with age as 25 years old and the following whose cognition on Internet finance for "unknown" accounted for $28.3 \%$ and those with age as 55 years old or above accounted for $42.9 \%$. Born in era of science and technology, young people are easiest to contact new things and to break tradition with innovation. Because of age or other reasons older people don't understand or want to learn some new thing.

\subsection{Analysis of usage for Internet finance products}

Table 5 the usage of the Internet finance products

\begin{tabular}{|c|c|c|c|}
\hline Questions & Options & number & proportion \\
\hline \multirow{3}{*}{$\begin{array}{l}\text { Whether to understand or use of the Internet } \\
\text { finance products such as "Yuebao" }\end{array}$} & Know and used it & 53 & $27.04 \%$ \\
\hline & Know but didn't use it & 62 & $31.63 \%$ \\
\hline & Unknown & 81 & $41.33 \%$ \\
\hline \multicolumn{2}{|l|}{ Total } & 196 & $100 \%$ \\
\hline \multirow{4}{*}{$\begin{array}{l}\text { the cause of using Internet finance products such } \\
\text { as "Yuebao" (Multi-select) }\end{array}$} & The higher expected return & 53 & $100 \%$ \\
\hline & Convenient & 48 & $90.57 \%$ \\
\hline & The lower fees & 40 & $75.47 \%$ \\
\hline & The lower threshold & 27 & $50.94 \%$ \\
\hline \multirow{3}{*}{ Whether to use $\mathrm{P} 2 \mathrm{P}$ lending platform } & Never heard of it & 135 & $68.88 \%$ \\
\hline & $\begin{array}{l}\text { Understand, but did not } \\
\text { participate in }\end{array}$ & 54 & $27.55 \%$ \\
\hline & Involved in & 7 & $3.57 \%$ \\
\hline \multicolumn{2}{|l|}{ Total } & 196 & $100 \%$ \\
\hline
\end{tabular}

Table 5 shows that respondent knows Internet finance products such as "Yuebao" accounts for 59\%. But those who used of it at the same time only accounts for $27.04 \%$. It accounts for $100 \%$ of the higher expected return among reasons using the Internet finance products such as "Yuebao" and accounts for $90.57 \%$ of using easily. As can be seen, it is the main reason for investors to use Internet finance products that Internet finance products can make up for the shortcomings of traditional financial and bring more revenue for them. The majority of respondents don't know about the P2P Internet finance, only $3.57 \%$ used. This is consistent with the "Yuebao" in stark contrast. Reason could be that people's participation is lower on the higher risk Internet finance products.

Table 6 the advantages and risks of the Internet finance

\begin{tabular}{|c|c|c|c|}
\hline Questions & Options & number & proportion \\
\hline \multirow{4}{*}{$\begin{array}{l}\text { The advantages of the Internet } \\
\text { finance (Multi-select) }\end{array}$} & Convenient and quick payment & 99 & $50.51 \%$ \\
\hline & Easy to apply & 55 & $28.06 \%$ \\
\hline & Full information & 45 & $23 \%$ \\
\hline & Can always pay attention to their wealth & 25 & $12.76 \%$ \\
\hline \multirow{4}{*}{$\begin{array}{l}\text { The risks of the Internet finance } \\
\text { (Multi-select) }\end{array}$} & $\begin{array}{l}\text { Internet technology was not fully } \\
\text { developed }\end{array}$ & 26 & $13.27 \%$ \\
\hline & Susceptible to criminals & 113 & $57.65 \%$ \\
\hline & $\begin{array}{l}\text { Error-prone for complex operations of } \\
\text { network computer }\end{array}$ & 26 & $13.27 \%$ \\
\hline & Be not assure of the Internet virtuality & 57 & $29.08 \%$ \\
\hline
\end{tabular}




\subsection{The analysis of the evaluation for Internet finance}

(1) The advantages and risk of the Internet finance

Table 6 shows the "payment convenience", "easy to apply" have become the main advantages of the Internet finance. It can be seen in the choice of financial planning approach, customers are very value convenience. About the "The risks of the Internet finance" option, up to $57.65 \%$ of respondents worry about "susceptible to criminals".

(2) Views about the future of Internet finance trends

Table 7 the future of Internet finance trends

\begin{tabular}{|l|c|c|}
\hline Options(Multi-select) & number & proportion \\
\hline $\begin{array}{c}\text { Become the main form of financial services to replace the dominant position } \\
\text { of banks }\end{array}$ & 37 & $18.88 \%$ \\
\hline Continue to develop, but the bank is still the subject of financial services & 78 & $39.8 \%$ \\
\hline $\begin{array}{c}\text { Change the development model of banks, ultimately rely on the banking } \\
\text { system to survive }\end{array}$ & 78 & $39.8 \%$ \\
\hline $\begin{array}{c}\text { Only be financial services temporarily spoiler, there will be no long-lasting } \\
\text { development }\end{array}$ & 12 & $6.12 \%$ \\
\hline
\end{tabular}

Table 7 shows that most respondents believe that Internet finance will continue to develop, but thought to replace the dominant position of banks accounted for only $18.88 \%$. It indicates that currently people are optimistic on the future development of Internet finance, but most of them don't think that the Internet finance can completely break the traditional finance landscape.

\section{Summary}

Theoretical analysis shows that the development of Internet finance broadens the personal finance channels, reduces the cost of personal finance and strengthens personal finance the security. Empirical analysis shows that relative to high-income families and low-income families, middle-income families learn more about Internet banking and people more understand about the Internet finance with higher proportion of household investment. Education and age also affect people's cognition on Internet finance. The data show that for people the higher education means more learn about Internet finance. In contrast, group of young than old know more about the Internet finance.

People in the pursuit of higher yields reject Internet finance products with high-risk. People recognize "convenient payment", "time-saving" and other advantages of the Internet finance, but also misgive on the "Susceptible to criminals" and other shortcomings of it. For the prospects of Internet finance, most people are still more optimistic, but they don't think the Internet can replace the Bank's current position.

\section{Acknowledgments}

This research was supported by grants from innovation and business plan project for undergraduates of Heilongjiang department of education (No. 20141022307), the social philosophy planning project of Daqing (No.DSGB2016020), the school cultivation subject of Heilongjiang Bayi Agricultural University (No.XRW2014-08).

\section{References}

[1]. Allen F, Gale D. Financial markets, intermediaries, and intertemporal smoothing [J]. Journal of Political Economy. Vol. 105 (1997) No.03, p. 523-546.

[2]. Mishkin F S. The economics of money, banking, and financial markets [M]. Pearson education, 2007, p. 59-61. 
[3]. Qiu Peng. Research for the challenge of Commercial Banks faced from the third-party payment [J].Huabei Finance. (2013).No.07, p. 41-44.

[4]. Guo Chang. Present situation, trend and prospect of Internet finance [J]. Industrial \& Science Tribune. Vol 12 (2013) No.19, p. 16-17.

[5]. Chen Xiaotian. The impact on bank personal finance business from Internet finance [J].Market weekly. (2014). No. 05, p. 90-91.

[6]. Zhuang Bozhen, Wang Zhiyong. Prevention and development trend of Internet finance risk in China [J].Times Finance. (2014). No. 05, p. 66-68. 